\title{
Telenomus cyamophylax, n. sp. (Hymenoptera: Scelionidae) Attacking Eggs of the Velvetbean Caterpillar, Anticarsia gemmatalis Hübner (Lepidoptera: Noctuidae)
}

\author{
Andrew Polaszek ${ }^{1}$ and Luis A. Foerster ${ }^{2}$ \\ ${ }^{1}$ Intemational Institute of Entomology (an Institute of CAB Intemational), 56, \\ Queen's Gate, London SW7 5JR, U.K. \\ ${ }^{2}$ Departamento de Zoologia, Universidade Federal do Paraná, Caixa postal \\ 19.020, 81.531-990, Curitiba, PR. \\ An. Soc. Entomol. Brasil 26(1):177-181 (1997) \\ Telenomus cyamophylax, sp. n. (Hymenoptera: Scelionidae) Parasitando Ovos \\ da Lagarta da Soja Anticarsia gemmatalis Hübner (Lepidoptera: Noctuidae)
}

RESUMO - Telenomus cyamophylax Polaszek, sp.n. é descrita a partir de adultos emergidos de ovos de Anticarsia gemmatalis Hübner (Lepidoptera: Noctuidae). A nova espécie pertence ao grupo californicus sensu Johnson, 1984. Dados biológicos, incluindo um hospedeiro alternativo, são apresentados.

PALAVRAS-CHAVE: Insecta, controle biológico, parasitóide de ovos, soja.

\begin{abstract}
Telenomus cyamophylax Polaszek, $\mathrm{n}$. sp. is described from the eggs of the soybean pest velvetbean Anticarsia gemmatalis (Hübner) (Lepidoptera: Noctuidae) caterpillar. This new species belongs to the californicusgroup sensu Johnson, 1984. Biological data, including one alternative host, are given.
\end{abstract}

KEY WORDS: Insecta, biological control, egg parasitoid, soybean.

The family Scelionidae is entirely composed of egg parasitoids, and includes many species of economic importance as parasitoids of agricultural insect pests (Bin \& Johnson 1982, Orr 1988). Trissolcus basalis (Wollaston) and Telenomus podisi Ashmead are the most important scelionid egg parasitoids of stink bugs (Heteroptera: Pentatomidae) in Brazil (Corrêa-Ferreira 1986, Foerster \& Queiroz 1990). Telenomus remus Nixon has been introduced against Spodoptera spp. in many tropical countries, particularly in South and Central America and the Caribbean islands, and successes have been claimed in several cases (e. g., Venezuela, Hemandez et al. 1989). Various other species of Telenomus are reported attacking eggs of other lepidopterous families, for example $T$. dalmanni (Ratz.) in Lymantriidae (De Santis \& Vidal-Sarmiento 1979), T. alceio (J.C. Crawford) and other members of the T. californicus Ashmead group in Pyraloidea (Lima-Filho et al. 1979, Pimentel et al. 1991), T. dilophonotae Cameron and T. connectans Ashmead in Sphingidae (Abreu et al. 1989, Johnson 1990), as well as unidentified species of Telenomus in Lasiocampidae (Fischer \& Patel 1993) and Saturniidae (Winder 1976). 
Soybean pest management programmes have been in progress in Brazil since 1975 (Kogan et al. 1977) and stink bug populations have been successfully reduced by large scale releases of T. basalis (Corrêa-Ferreira 1993). The control of lepidopterous larvae, however is largely dependent on chemicals and little effort has been dedicated to the detection of potential natural enemies, such as egg parasitoids. The main defoliator of soybeans is the velvetbean caterpillar Anticarsia gemmatalis Hübner (Lepidoptera: Noctuidae) and only Trichogramrna pretiosum Riley (Hymenoptera: Trichogrammatidae) was previously known to parasitize eggs of $A$. gemmatalis in Brazil (Hohmann et al. 1989). Field surveys carried out during the soybean growing seasons of 1994/95 and 1995/96 in Southern Paraná State revealed the occurrence of two other species of egg parasitoids of A. gemmatalis: Trichogramma rojasi Nagaraja \& Nagarkatti and an undescribed species of Telenomus, which is the object of the present study.

The existence of a complex of species parasitizing eggs of A gemmatalis indicates that management programmes can be implemented for the velvetbean caterpillar through preservation and augmentation of these species. In this paper, the description of this species is given, together with preliminary biological data obtained in the laboratory.

\section{Materials and Methods}

Telenomus were reared from eggs of $A$. gemmatalis collected in a soybean crop in the locality of Lapa, Paraná State, southern Brazil. Specimens were prepared for taxonomic study following the method described in detail by Polaszek \& Kimani (1990) requiring card-mounting, followed by slide-mounting male genitalia in Canada Balsam. Morphological terminology follows Johnson (1984). The holotype and several paratypes are deposited in the collections of the Department of Entomology, The Natural History Museum, London $(\mathrm{BMNH})$. Remaining paratypes are deposited in the Department of Entomology,
United States National Museum, Washington (USNM) and in the Entomological Collection "Jesus S. Moure" (DZUP), Curitiba, PR, Brazil.

Taxonomy. The genus Telenomus has been little studied at species-level. The western Palaearctic species have been keyed and diagnosed by Kozlov \& Kononova (1983), based on female morphology. Unfortunately, the most useful character for species recognition in $T e$ lenomus, at least in several species-groups, is the form of the male genitalia (Johnson 1984, Polaszek \& Kimani 1990). Johnson (1984) has made considerable progress towards our understanding of species groups, and of several Nearctic species within some of those groups, and has also produced an invaluable catalogue of world species (Johnson 1992). However, the Neotropical species still remain largely unstudied. Johnson (1992) lists 69 species from the Neotropics, of which several are probably synonyms, and probably many times that number are still undescribed. For the purposes of this description it was not considered worthwhile either tracking down each available type specimen for comparison, or consulting all 69 original descriptions (in many cases largely useless anyway) in order to ascertain beyond doubt that the species described here is new to science. We can at least usefully characterize this species here, and make the name available for studies to develop I PM of soybean which includes A. gemmatalis. If a future revision reveals $T$. cyamophylax to be a junior synonym of some other species, this would be unfortunate, but by no means disastrous.

\section{Telenomus cyamophylax Polaszek, new species}

Male. General coloration dark brown to black, the fore tibiae and all tarsi paler brown. Genitalia (Fig. 1): Aedeagal lobe about one third the total length of the aedeago volsellar shaft, truncate. Digiti large, about half the maximum length of the aedeagal lobe, with three (occasionally four) digital teeth per digitus, teeth 


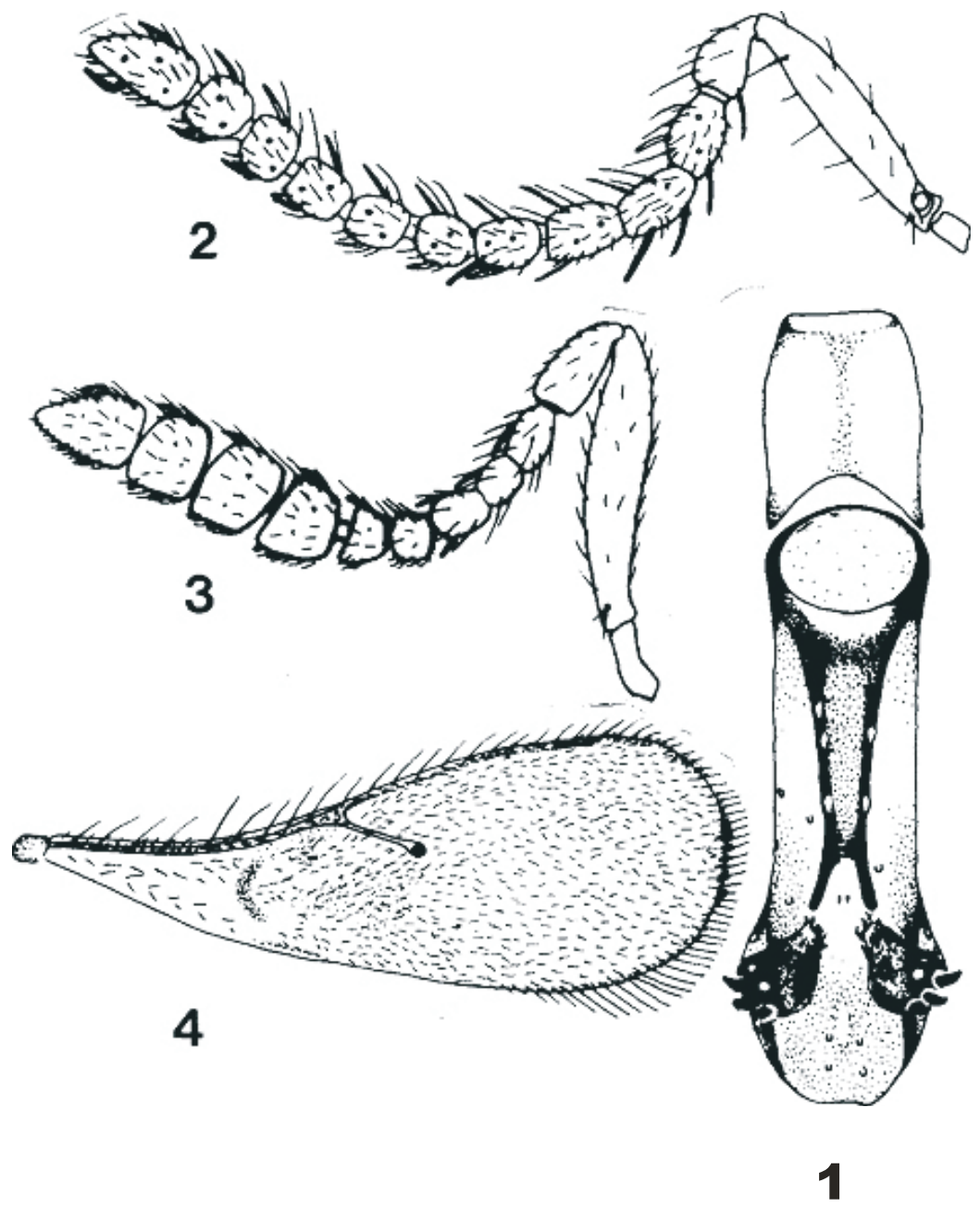

Figures 1-4. Telenomus cyamophylux sp. n. 1. male genitalia; 2. male antenna; 3. female antenna; 4. fore wing.

long and robust. Central projection absent. Head with frons entirely smooth and shining, some large reticulation at vertex and around lateral ocelli. Vertex sharply angled, but not carinate. Antennae as in Fig. 2, a prominent sensillum on A5. Eyes hairy. Mesoscutum without notauli, dorselium approximately rectangular, finely sculptured. Fore wing (Fig. 4) with some infuscation at the base and behind the stigmal vein. Tl of metasoma with two pairs of lateral setae, a single pair of sublateral setae. Basal costae on T2 short. General habitus somewhat 'humpbacked' because of the strongly convex mesosoma and the relatively low attachment of the transverse head.

Female. Head with antenna 11-segmented, clava 5-segmented with A6-10 transverse (Fig. 
3); mesosoma and metasoma without any easily observed distinctive characters.

Remarks. T. cyamophylax belongs to the californicus-group sensu Johnson (1984). Superfícially it strongly resembles $T$. remus Nixon, in particular by the 'humpbacked' appearance due to the fact that the transverse head is carried relatively low on the convex mesosoma. No doubt there are several other Neotropical Telenomus species, unknown to the authors, that share this character. T. remus is also a noctuid parasitoid, attacking eggs of Spodoptera spp.

Material Examined. Holotype: male, BRAZIL: Paraná State, Lapa., February, 1996 ex A. gemmatalis on soybean (L.A, Foerster) (BMNH, genitalia, one antenna and fore wing on slide TC 1). Paratypes 12 males, 12 females, same data as holotype (BMNH, USNM, DZÜP).

Hosts. Noctuidae Anticarsia gemmatalis Hübner, Pseudaletia sequax Franclemont.

Distribution. Known so far from Brazil only. Given that A gemmatalis is widespread in the Americas, from U. S.A. to Chile, T. cyamophylax is almost certainly more widely distributed.

Biological Data. This species has been successfully reared in laboratory for over 20 generations using eggs of $A$. gemmatalis as hosts. Development from oviposition to adult emergence is inversely proportional to temperature, and ranges from 14 days at $29^{\circ} \mathrm{C}$ to 40 days at $17^{\circ} \mathrm{C}$. Adult longevity was also influenced by the temperature, and survival ranged from 13 days at $29^{\circ} \mathrm{C}$ to 40 days at $17^{\circ} \mathrm{C}$. Apart from A gemmatalis, T. cyamophylax also developed and reproduced in eggs of the armyworm Pseudaletia sequax Franclemont (Lepidoptera: Noctuidae), but was unable to parasitize eggs of Spodoptera latifascia Walker in laboratory.

\section{Acknowledgements}

Space and facilities during part of this study were kindly provided to the first author by the Department of Entomology, The Natural History Museum, London. Prof . Norman F. Johnson, Ohio State University, is thanked for his advice.

\section{Literature Cited}

Abreu, J.M. de, R.B. Sgrillo,W.R.Thompson \& A. J. Nicholson. 1989. Parasitismo de ovos de Erinnyis ello (Lepidoptera: Sphingidae) por Telenomus dilophonotae e T. connectans (Hymenoptera: Scelionidae) em seringais da Bahia, Brasil. Agrotropica 1: 137-143.

Bin, F. \& N.F. Johnson. 1982. Potential of Telenominae in biocontrol with egg parasitoids (Hym., Scelionidae). Colloques del'INRA 9: 275287

Corrêa-Ferreira, B. S. 1986. Ocorrência natural do complexo de parasitóides de ovos de percevejos da soja no Paraná. An. Soc. Entomol. Brasil 15: 189-199.

Corrêa-Ferreira, B.S. 1993. Utilização do parasitóide de ovos Trissolcus basalis (Wollaston) no controle de percevejos da soja. Londrina, EMBRAPA, Circ. Téc. $11,40 \mathrm{p}$.

De Santis, L. \& J.A. Vidal-Sarmiento. 1979. Três espécies interesantes de escelionidos de la Republica Argentina y de Chile (Hymenoptera: Proctotrupoidea). Idesia 5: 147-150.

Fischer, H.Z. \& RN. Patel. 1993. Fluctuacion poblacional y comportamiento de mariposas (Lepidoptera: Lasiocampidae) y de sus parasitóides (Hymenoptera and Diptera) en aguacate (Persea americana). Rev. Biol. Trop. 41: 515-519. 
Foerster, LA. \& J.M. Queiroz. 1990. Incidência natural de parasitismo em ovos de pentatomídeos da soja no Centro-Sul do Paraná. An. Soc. Entomol. Brasil 19:221232.

Hernandez, D., Ferrer, F. \& Linares, B. 1989. Introduccion de Telenomus remus Nixon (Hym.: Scelionidae) para controlar Spodoptera frugiperda (Lep.: Noctuidae) enYaritagua Venezuela. Agron. Trop., Maracay $39: 46$

Hohmann, C.L., S.M.T. Silva \&W.J. Santos. 1989. Lista preliminar de Trichogrammatidae encontrados no Paraná. An. Soc. Entomol. Brasil 18:203-206.

Johnson,N.F. 1984. Systematics of Nearctic Telenomus Classification and revisions of the podisi and phymatae groups. Buli. OhioBiol.Surv.6(3),113p.

Johnson,N.F. 1990. Telenomus (Hymenoptera: Scelionidae) egg parasites of Erinnyis ello (Lepidoptera: Sphingidae). Proc. Entomol. Soc. Wash. 92: 306-309.

Johnson, N.F. 1992. Catalog of worid Proctotrupoidea excluding Platygastridae. Mem. Am. Entomol. Inst. 51:1 825

Kogan, M., S.G.Tumipseed, M. Shepard, E.B. Oliveira \& A. Borgo. 1977. Pilot insect pest management program for soybean in Southern Brazil. J. Econ. Entomol. 70: 659-663.
Kozlov, M.A. \& S.V. Kononova. 1983. Telenominy fauny SSSR (Hymenoptera, Scelionidae, Telenominae). Opredeliteli po Faune SSSR 136: 1-335

Lima Filho, M., G.M. Riscado \& J.T. Barbosa. 1979. Comportamento da broca da canade-açucar, Diatraea spp. no estado do Rio de Janeiro no triênio 1975-77. An. Soc. Entomol. Brasil 8: 257-280.

Orr, D. B. 1988. Scelionid wasps as biological control agents: A review. Fla. Entomol. 71: 501-506.

Pimentel, M. C. P., M. V. Macedo \& R. F. Monteiro. 1991. Notes on the biology and behaviour of Eupastranaia fenestrata Menetries (Lepidoptera: Pyralidae: Midilinae). J. NewYork Entomol. Soc. 99: 699-700.

Polaszek,A. \& S.W. Kimani. 1990. Telenomus species (Hymenoptera: Scelionidae) attacking eggs of pyralid pests (Lepidoptera) in Africa: a review and guide to identification. Bull. Entomol. Res. 80: 57-71.

Winder, J.A. 1976. Some observations on a Hylesia species probably fulviventris Berg (Lepidoptera, Saturniidae) which attacks Lantana trifolia in Paraná State. Dusenia9: 29-30.

Received 19/IX/96. Accepted 24/I11/97. 